\title{
Hotel Guests' Perceptions of Green Technology Applications, and Practices in the Hotel Industry
}

Faranak Memarzadeh, San Jose State University, San Jose, USA

Sulekha Anand, San Jose State University, San Jose, USA

\begin{abstract}
Although sustainability and technology are two major concerns in the lodging industry, sustainability applications and practices are quite new and in need of more research. This study was conducted to examine and understand hotel guests' perceptions of green technology applications and practices. Data were collected in 2018 from 210 respondents via an online survey. The Technology Acceptance Model was applied to examine how ease of use and usefulness of green technology applications and practices can influence guests' booking decisions. The results showed significant positive correlations between behavioral belief and usefulness and between usefulness and intention to use green technology applications and practices. However, behavioral belief and ease of use were not correlated, nor were ease of use and intention to adopt green technology. These results demonstrate that guests do believe in the important role of green technology in sustainability and they intend to book hotels that adopt this technology.
\end{abstract}

\section{KEYWORDS}

Ease Of Use, Green Technology, Hotel Guests, Perception, Usefulness

\section{INTRODUCTION}

Promoting specific forms of tourism, influencing tourists' behavior, and supporting tourist-related products (such as hotels) are some of the principal objectives of sustainable tourism that can be achieved with sustainable technology practices (Ali and Frew, 2014). Recent research has emphasized the importance of two significant subjects in the hospitality industry, technology and sustainability. For example, Law, Buhalis and Cobanoglu (2014) discuss how the rapid development of technology provides extraordinary opportunities for hospitality businesses and Neuhofer, Buhalis, and Ladkin (2015) explain how progress in innovative technology creates opportunities for the service industry to offer optimal service. In the highly competitive service industry, technology can enhance the quality of offered services and provide more personized experiences for service users (Neuhofer et al., 2015).

Recent studies indicate a growing awareness of the importance of sustainability in the service industry. Jones, Hillier, and Comfort (2016) highlight increasing interest in supporting sustainability by both hotel owners and hotel guests. Green technology, which is the combination of technology and sustainability, is a new concept in the hotel industry that could satisfy both guests' and services' providers' desires for sustainability. The environmental impact of a product is a primary focus of green technology (Billatos, 1997). According to Dedrick (2010), the main reason for providers to adopt green technology is to decrease operating costs while minimizing the environmental impacts 
of running a business. From the users' standpoint, on the other hand, studies indicate that hotel customers have become more conscious about their environmental responsibilities when it comes to making decisions about purchasing certain products or services (Ramayah, Lee, \& Mohamad, 2010). However, no study has examined hotel guests' perceptions of green technology and their ratings of the efficiency and utility of these applications or practices. Therefore, the main objective of this study was to understand hotel guests' perceptions about green technology in the hotel industry using the Technology Acceptance Model (TAM) as a framework. According to this model, consumers' choice of whether to use a particular technology depends on its usefulness, defined as the efficiency of a certain practice, and its ease of use, defined as the user-friendliness of the technology (Davis, Bagozzi, \& Warshaw, 1989).

\section{LITERATURE REVIEW}

\section{The Importance of Sustainability in Economic Development}

Sustainability is defined as humans' approach towards nature, and their feeling of obligation towards each other and towards future generations (Baumgärtner and Quaas, 2010). In other words, sustainability can be defined as the relationship between humans and nature. Sustainability is a global concern that requires serious consideration especially from a business point of view (Legrand, Chen, \& Sloan, 2013). According to Elkington (1998), sustainability can be assessed at three different levels, economic, environmental, and social. In order to promote sustainability at the economic level, longterm regulations need to be imposed so that businesses protect the environment (Costanza, 1992). At the social and environmental levels, on the other hand, the production of a variety of environmentally friendly products enhances consumers' awareness about their impact on the environment (Theotokis \& Manganari, 2015).

\section{Green hotel practices}

Green hotel practices have been discussed from the points of view of both service providers (i.e., hoteliers) and consumers (i.e., hotel guests). The hotel industry has adopted various policies to support sustainability (Berezan, Millar, \& Raab, 2014). For instance, sustainability is being implemented by hotel operators at all different levels, from a fundamental level such as recycling waste to an advanced level such as obtaining sustainability certifications (Berezan et al., 2014). Berezan et al. (2014) found that recycling is rated by guests as the most important green practice in hotels, but the idea of not having the bed sheets changed on a daily basis is less favored by guests.

According to Zengeni, Zengeni, \& Muzambi (2013), there are several reasons for hotels to "go green;" one reason is government rules to adopt sustainability and another motive is the financial benefits of green practices. Green hotel practices can reduce costs, which eventually leads to greater financial benefits (Zengeni et al., 2013). For instance, strategies such as reducing energy and water use, replacing fossil fuels with renewable energy systems, and controlling food waste could increase hotel revenue. Mihalič, Žabkar, \& Cvelbar (2012) report that hoteliers and business owners confirm the profitability and cost-effectiveness of sustainability practices, so adopting sustainable practices can be considered a long-term financial investment (Berezan et al., 2014). Developing a positive public image can be another incentive for hotels to implement sustainable practices (Tzschentke, Kirk, \& Lynch, 2004).

\section{Green Technology Applications in the Hotel Industry}

Technology not only has a direct influence on promoting greener businesses (Bartlett \& Trifilova, 2010), but it also provides indirect benefits such as improving employee morale (Olson, 2008) and creating a positive corporate image (del Rio Gonzalez, 2005). Neuhofer et al. (2015) argue that business owners have two principal motives for considering green technology in particular. First, 
the service industry is a fast-growing marketplace (Zach, Gretzel, \& Xiang, 2010), and second, technology is considered a competitive advantage that enhances the effectiveness and efficiency of the business (Buhalis \& Law, 2008). The efficiency of the business is influenced for two different reasons (Capra, Francalanci, \& Slaughter 2012). The functionality of technology-based devices is much more advanced than traditional devices, such as a hotel room control system, which turns the power on when the guest enters the hotel room, and automatically turns it off when the guest leaves. Utilizing such technology improves energy efficiency. Moreover, since these devices are technologybased, users are constantly being encouraged to upgrade to maximize functionality so that users have the latest technology. These concepts align with the findings of Ali and Frew's study (2014) which suggests that green hospitality can be more effective if innovative technology applications or practices are adopted by hoteliers.

Green hotel technologies are environmentally friendly systems that are utilized to reduce the environmental impact of the hotels by controlling water and energy consumption and decreasing waste (Gagić, Jovičić, \& Erdeji, 2013). Millar and Baloglu (2011) explain that one of the most significant hotel room preferences is green hotel certification such as Leadership in Energy and Environmental Design (LEED), which not only benefits business but also attracts eco-conscious guests.

Another advanced technology that can be employed in the hospitality industry is machine learning (Berthelsen, 2017), a computational procedure that simulates human intelligence by learning from the environment (El Naqa \& Murphy, 2015). Since machine learning has the ability to precisely forecast demand, companies like hotels can use it to predict almost the exact amount of required inventory and labor, which will enhance the company's efficiency while simultaneously reducing costs (Berthelsen, 2017).

\section{METHODOLOGY}

\section{Theoretical Framework and Hypotheses}

This study was designed to determine hotel guests' perceptions of green technology within the framework of the Technology Acceptance Model (TAM). Davis (1986) introduced TAM as an additional feature of the Theory of Reasoned Action (TRA) which had been introduced earlier by Fishbein and Ajzen (1977). TRA is the theoretical foundation of TAM that connects important factors such as the ease of use of a certain system, the degree of usefulness of the system, and the way the system is perceived by the user (Davis et al., 1989).

Davis (1989) defined ease of use and usefulness from the individual's behavioral? standpoint. Users adopt a particular system if they believe the system would increase the outcome of a specific behavior and he defined this as the usefulness of the system. Ease of use, on the other hand, is the degree to which an individual believes that using a particular system will be easy; thus, a system that appears easier to use will have a greater chance of acceptance by users (Davis, 1989).

The current study tested the following hypotheses, based on the TAM, to evaluate to the degree to which guests' intention to purchase a hotel room, the dependent variable, can be influenced by the ease of use and usefulness of the hotels' green technology (the independent variables) as shown in Figure 1.

Hypothesis 1: There is a positive correlation between behavioral belief and ease of use of green technology.

Hypothesis 2: There is a positive correlation between behavioral belief and usefulness of green technology.

Hypothesis 3: There is a positive correlation between ease of use and intention to use green technology. Hypothesis 4: There is a positive correlation between usefulness and intention to use green technology. 


\section{Data Analysis}

An online survey was administered in the summer of 2018 to evaluate respondents' behavioral beliefs on green technology in hotels (4 questions), opinions on ease of use of technology (8 questions), opinions on the usefulness of green technology (5 questions), and their intention to utilize green technology (4 questions). For each of these questions, there was a 5 point Likert scale with 1 indicating Strongly Disagree and 5 indicating Strongly Agree. Demographic information was also collected.

Qualtrics was used to recruit 210 respondents and to obtain their responses to the survey questions. The inclusion criteria were: at least 18 years of age, familiar with technology such as mobile apps, recent stay (within the last year) in a hotel in the US, and have used green technology in a hotel.

SPSS 25 was used for computation of scale scores, descriptive statistics, and Pearson's correlation analysis. Reverse coding was implemented for negatively worded questions before scale scores were calculated. The responses to pertinent questions were summed to obtain the scale scores for the behavioral belief, ease of use, usefulness, and intention to utilize constructs. SPSS Amos 25 was used for structural equation modeling to test the model depicted in Figure 2. Cronbach's $\alpha$ for the items on this survey was 0.917 .

\section{RESULTS}

There were no missing data. The demographic characteristics of the sample are summarized in Table 1. Most respondents (56\%) stayed at a hotel between 2 and 5 times a year and used green technology often or always during hotel stays (71\%). Fifty-four percent of respondents reported that their stays were typically for leisure purposes, $12 \%$ reported mainly staying for business purposes, and $34 \%$ reported that their stays were approximately equal for both purposes. Most respondents were between 25 and 44 years of age (59\%). Sixty-five percent of the respondents were female, and $73 \%$ of the respondents were white. Almost 50\% of respondents reported an annual income of $\$ 40,000$ to $\$ 100,000$, and $55 \%$ of respondents had completed at least a four-year college degree.

The most frequently reported uses of green technology were going paperless (58\% of respondents report this use), eco-friendly heating and air conditioning technology (54\%), sustainable laundry (49\%), and smart keys for lighting control and recording of water consumption (48\%), followed by on-site recycling (33\%).

All pairwise Pearson's correlations between scale scores were statistically significant except for the correlations between ease of use and the other scale scores (Table 2). For structural equation modeling, there were no missing data and therefore no estimation was required. The overall model was statistically significant, $\chi^{2}(2)=29.321, \mathrm{p}<0.05$. Figure 2 shows the model tested along with

Figure 1. Shows the TAM model that was tested for this research

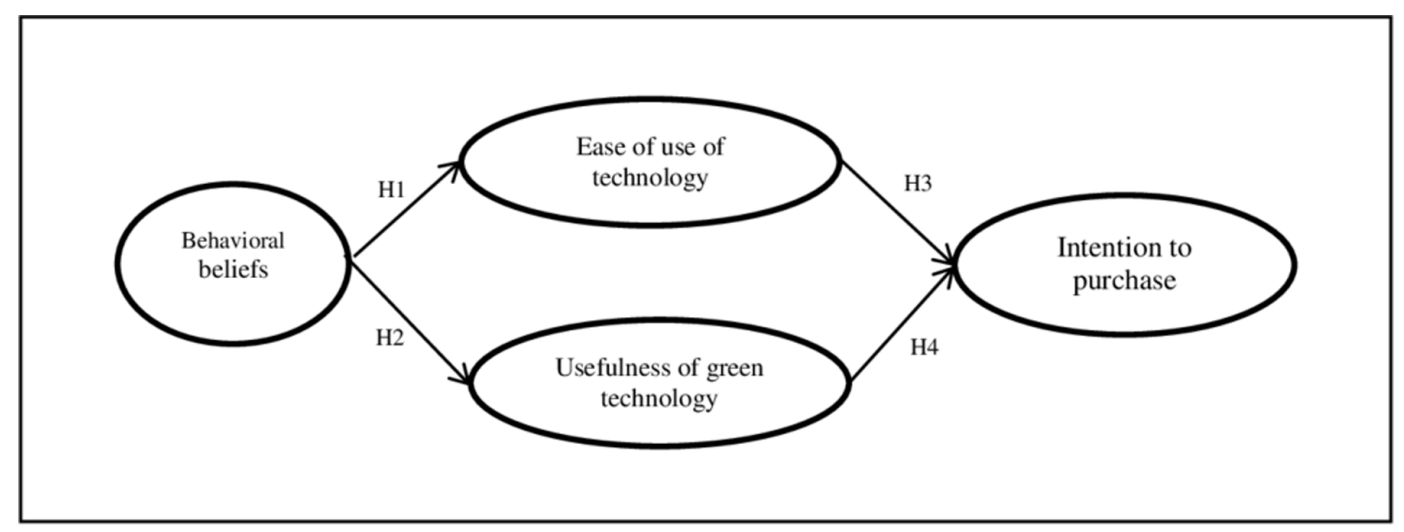




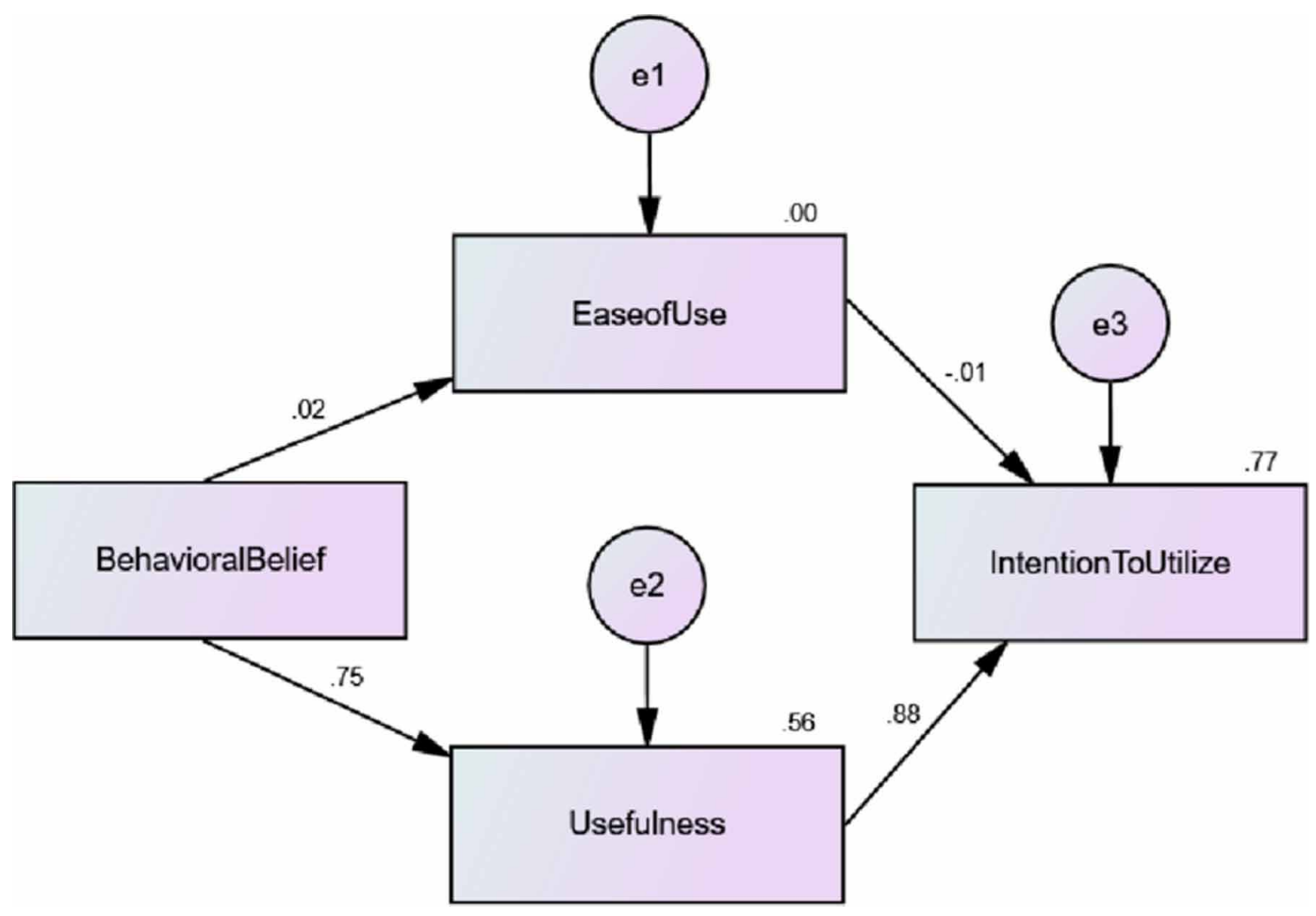

the standardized regression weights. The path from behavioral belief to usefulness was statistically significant; the usefulness score increases by 0.75 for every 1 point increase in behavioral belief score. The path from usefulness to intention to utilize was also statistically significant, such that the intention to utilize score increases by 0.88 for every 1 point increase in usefulness score.

While some previous studies found a positive correlation between ease of use and behavioral belief with intention to use (Park, Nam, \& Cha, 2012), other studies are consistent with the current study's finding of no significant correlation between ease of use and behavioral belief with the intention to use (Memarzadeh, Blum, \& Adams, 2016). These discrepant results could be due to how the users evaluate the importance of the specific technology or devices in these studies.

Responses to individual questions indicated that respondents' overall evaluation of the quality of offered service is impacted by the hotel's use of green technology and consequently they have a greater intention to book the hotel. Hotels with green technology influence guests' perceptions in two different ways: first, using this technology enhances guests' satisfaction because they believe that the quality of hotel service is linked to the green technology that the hotel uses. Second, by using this technology guests feel more confident because they are being environmentally responsible.

Several factors were identified that can influence respondents' decisions to use green technology, such as the cost associated with adopting green technology, the type of green technology, functionality of the green technology, the way the technology impacts the environment, and the incentives associated with the green technology. 
Table 1. Demographic characteristics of the respondents in the sample studies, $n=210$

\begin{tabular}{|c|c|}
\hline DEMOGRAPHIC & FREQUENCY (PERCENTAGE) \\
\hline \multicolumn{2}{|l|}{ Gender } \\
\hline Male & $73(34.8 \%)$ \\
\hline Female & $136(64.8 \%)$ \\
\hline Transgender & $1(0.5 \%)$ \\
\hline \multicolumn{2}{|l|}{ Age Group } \\
\hline $18-24$ years & $20(9.5 \%)$ \\
\hline 25-34 years & $67(31.9 \%)$ \\
\hline $35-44$ years & $56(26.7 \%)$ \\
\hline $45-54$ years & $25(11.9 \%)$ \\
\hline 55 years and up & $42(20.0 \%)$ \\
\hline \multicolumn{2}{|l|}{ Race/Ethnicity } \\
\hline African American & $19(9.0 \%)$ \\
\hline Asian & $10(4.8 \%)$ \\
\hline Hispanic & $22(10.5 \%)$ \\
\hline Native American & $3(1.4 \%)$ \\
\hline White & $154(73.3 \%)$ \\
\hline Other & $2(1.0 \%)$ \\
\hline \multicolumn{2}{|l|}{ Highest Level of Education } \\
\hline Less than high school & $1(0.5 \%)$ \\
\hline High school/GED & $27(12.9 \%)$ \\
\hline Some college & $32(15.2 \%)$ \\
\hline 2-year college degree & $34(16.2 \%)$ \\
\hline 4-year college degree & $72(34.3 \%)$ \\
\hline Master's degree or higher & $44(21.0 \%)$ \\
\hline \multicolumn{2}{|l|}{ Personal Income Level } \\
\hline Less than $\$ 40,000$ & $47(22.4 \%)$ \\
\hline$\$ 40,000-\$ 80,000$ & $59(28.1 \%)$ \\
\hline$\$ 80,001-\$ 100,000$ & $44(21.0 \%)$ \\
\hline$\$ 100,001-\$ 120,000$ & $18(8.6 \%)$ \\
\hline$\$ 120,001-\$ 140,000$ & $10(4.8 \%)$ \\
\hline More than $\$ 140,000$ & $32(15.2 \%)$ \\
\hline
\end{tabular}

\section{CONCLUSION AND IMPLICATIONS}

The significant value that green technology adds to the hotel industry can be evaluated from the guests' point of view as well as the hotelier's point of view. The current study evaluated the influence of green technology applications or practices on guests' intention to book a hotel room (i.e., the guests' point of view). The results of the study revealed that guests' behavioral beliefs positively impact their perception of the usefulness of green technology. On the other hand, guests' behavioral beliefs are not 
Table 2. Pearson's correlation analysis

\begin{tabular}{|l|l|l|l|}
\hline & \multicolumn{1}{|c|}{ Usefulness } & \multicolumn{1}{c|}{ Intention to Utilize } & \multicolumn{1}{c|}{ Ease of Use } \\
\hline Behavioral Belief & $0.747^{*}$ & $0.769^{*}$ & 0.023 \\
\hline Usefulness & & $0.877^{*}$ & 0.055 \\
\hline Intention to Utilize & & & 0.042 \\
\hline
\end{tabular}

$\left(^{*}\right)$ indicates that the result is statistically significant at the 0.05 level

influenced by the ease of use of this technology, so guests would book a hotel with green technology regardless of how complicated its use might be.

Previous studies, on the other hand, evaluated green technology from the hoteliers' and business owners' points of view. These studies demonstrated the profitability and cost-effectiveness of sustainable technologies and practices (Mihalič et al., 2012). Therefore, implementing green technology can be considered a long-term financial investment (Berezan et al., 2014), a substantial incentive for the hotel business.

Understanding guests' perception of green technology will help hoteliers to develop and implement green technology practices to match guests' needs and priorities. Since guests are willing to contribute to protecting the environment, it would be the hoteliers' and technology developers' responsibility to reduce or even eliminate the cost associated with adoption. A practical solution that can reduce the cost associated with green technology could be a competitive advantage for the hotel. For instance, offering a special discount or bonus for frequent users could be an incentive strategy that not only encourages guests to stay committed to their environmental responsibility but also keeps guests loyal to the hotel brand.

Hoteliers and application developers must simplify green technology applications as much as possible to make them user-friendly. Guests need to be educated on the functionality and how the application or practice would impact the environment. This study has shown that obtaining feedback from guests who have utilized green technology is a practical solution to learn how the technology is perceived by hotel guests.

\section{LIMITATIONS}

There are some limitations to this study. For example, respondents were recruited via Qualtrics, making this a convenience sample. Moreover, the respondents all resided in the US, and the trends may differ for a global sample. The focus on TAM in this study led to the evaluation of usefulness and ease of use of green technology applications and practices. Future studies could examine other factors that could influence guests' perceptions of green technology such as length of trip, type of trip and destination of the trip. 


\section{REFERENCES}

Ali, A., \& Frew, A. J. (2014). Technology innovation and applications in sustainable destination development. Information Technology \& Tourism, 14(4), 265-290. doi:10.1007/s40558-014-0015-7

Bartlett, D., \& Trifilova, A. (2010). Green technology and eco-innovation: Seven case-studies from a Russian manufacturing context. Journal of Manufacturing Technology Management, 21(8), 910-929. doi: $10.1108 / 17410381011086757$

Baumgärtner, S., \& Quaas, M. (2010). What is sustainability economics? Ecological Economics, 69(3), 445-450. doi:10.1016/j.ecolecon.2009.11.019

Berezan, O., Millar, M., \& Raab, C. (2014). Sustainable hotel practices and guest satisfaction levels. International Journal of Hospitality \& Tourism Administration, 15(1), 1-18. doi:10.1080/15256480.2014.872884

Berthelsen, C. (2017, December 6). Machine learning can make hospitality businesses more predictable. Fourth. Retrieved from https://www.fourth.com/en-gb/blog/machine-learning-can-make-hospitality-businesses-morepredictable

Billatos, S. (1997). Green technology and design for the environment. CRC Press.

Buhalis, D., \& Law, R. (2008). Progress in information technology and tourism management. 20 years on and 10 years after the internet. The state of tourism research. Tourism Management, 29(4), 609-623. doi:10.1016/j. tourman.2008.01.005

Capra, E., Francalanci, C., \& Slaughter, S. A. (2012). Is the software "green"? Application development environments and energy efficiency in open source applications. Information and Software Technology, 54(1), 60-71. doi:10.1016/j.infsof.2011.07.005

Costanza, R. (1992). Ecological economics: the science and management of sustainability. Columbia University Press.

Davis, F. D. (1986). A Theology Acceptance Model for Empirically Testing New end-User Information Systems: Theory and Results [Doctoral dissertation]. Sloan School of Management. Massachusetts Institute of Technology.

Davis, F. D. (1989). Perceived usefulness, perceived ease of use, and user acceptance of information technology. Management Information Systems Quarterly, 13(3), 319-340. doi:10.2307/249008

Davis, F. D., Bagozzi, R. P., \& Warshaw, P. R. (1989). User acceptance of computer technology: A comparison of two theoretical models. Management Science, 35(8), 982-1003. doi:10.1287/mnsc.35.8.982

Dedrick, J. L. (2010). Green IS: Concepts and issues for information systems research. CAIS, $27(1), 11$.

Del Río González, P. (2005). Analyzing the factors influencing clean technology adoption: A study of the Spanish pulp and paper industry. Business Strategy and the Environment, 14(1), 20-37. doi:10.1002/bse.426

Devitt, J. H., Kurrek, M. M., Cohen, M. M., Fish, K., Fish, P., Noel, A. G., \& Szalai, J. P. (1998). Testing internal consistency and construct validity during evaluation of performance in a patient simulator. Anesthesia and Analgesia, 86(6), 1160-1164. PMID:9620496

El Naqa, I., \& Murphy, M. J. (2015). What is machine learning? In Machine Learning in Radiation Oncology (pp. 3-11). Cham: Springer. doi:10.1007/978-3-319-18305-3_1

Elkington, J. (1998). Partnerships from cannibals with forks: The triple bottom line of 21st-century business. Environmental Quality Management, 8(1), 37-51. doi:10.1002/tqem.3310080106

Fishbein, M., \& Ajzen, I. (1977). Belief, attitude, intention, and behavior: An introduction to theory and research.

Gagić, S., Jovičić, A., \& Erdeji, I. (2013, September). Green technologies in the hospitality industry. In Environmental protection of urban and suburban settlements. In Proceedings of the XVII International EcoConference (pp. 515-523). Academic Press.

Jones, P., Hillier, D., \& Comfort, D. (2016). Sustainability in the hospitality industry: Some personal reflections on corporate challenges and research agendas. International Journal of Contemporary Hospitality Management, 28(1), 36-67. doi:10.1108/IJCHM-11-2014-0572 
Law, R., Buhalis, D., \& Cobanoglu, C. (2014). Progress on information and communication technologies in hospitality and tourism. International Journal of Contemporary Hospitality Management, 26(5), 727-750. doi:10.1108/IJCHM-08-2013-0367

Legrand, W., Chen, J. S., \& Sloan, P. (2013). Sustainability in the Hospitality Industry (2nd ed.). Routledge.

Memarzadeh, F., Blum, S. C., \& Adams, C. (2016). Business travelers' intention to purchase: The application of the technology acceptance model (TAM). Journal of Quality Assurance in Hospitality \& Tourism, 17(4), 412-424. doi:10.1080/1528008X.2015.1096755

Mihalič, T., Žabkar, V., \& Cvelbar, L. K. (2012). A hotel sustainability business model: Evidence from Slovenia. Journal of Sustainable Tourism, 20(5), 701-719. doi:10.1080/09669582.2011.632092

Millar, M., \& Baloglu, S. (2011). Hotel guests' preferences for green guest room attributes. Cornell Hospitality Quarterly, 52(3), 302-311. doi:10.1177/1938965511409031

Neuhofer, B., Buhalis, D., \& Ladkin, A. (2015). Smart technologies for personalized experiences: A case study in the hospitality domain. Electronic Markets, 25(3), 243-254. doi:10.1007/s12525-015-0182-1

Olson, E. G. (2008). Creating an enterprise-level "green" strategy. The Journal of Business Strategy, 29(2), 22-30. doi:10.1108/02756660810858125

Park, S. Y., Nam, M. W., \& Cha, S. B. (2012). University students' behavioral intention to use mobile learning: Evaluating the technology acceptance model. British Journal of Educational Technology, 43(4), 592-605. doi:10.1111/j.1467-8535.2011.01229.x

Ramayah, T., Lee, J. W. C., \& Mohamad, O. (2010). Green product purchase intention: Some insights from a developing country. Resources, Conservation and Recycling, 54(12), 1419-1427. doi:10.1016/j. resconrec.2010.06.007

Theotokis, A., \& Manganari, E. (2015). The impact of choice architecture on sustainable consumer behavior: The role of guilt. Journal of Business Ethics, 131(2), 423-437. doi:10.1007/s10551-014-2287-4

Tzschentke, N., Kirk, D., \& Lynch, P. A. (2004). Reasons for going green in serviced accommodation establishments. International Journal of Contemporary Hospitality Management, 16(2), 116-124. doi:10.1108/09596110410520007

Zach, F. J., Gretzel, U., \& Xiang, Z. (2010). Innovation in web marketing programs of American convention and visitor bureaus. Information Technology \& Tourism, 12(1), 47-63. doi:10.3727/109830510X12747489979628

Zengeni, N., Zengeni, D. M. F., \& Muzambi, S. (2013). Hoteliers' Perceptions of the Impacts of Green Tourism on Hotel Operating Costs in Zimbabwe: The Case of Selected Harare Hotels. Australian Journal of Business and Management Research, 2(11), 64.

Faranak Memarzadeh is an assistant professor in the department of Hospitality, Tourism and Event Management at San Jose State University. She received her Ph.D. at Texas Tech University in Hospitality Administration. In addition to teaching, Dr. Memarzadeh is a reviewer for several journals and conferences, such as Journal of Hospitality Marketing and Management, Journal of Quality Assurance in Hospitality and Tourism, and Hospitality Graduate Conference. Her primary research interests are in innovation and sustainable operations, consumer behavior, online media, and marketing. She has professional experience working with hotels and hospitality companies such as Hilton and Marriott Courtyard. 